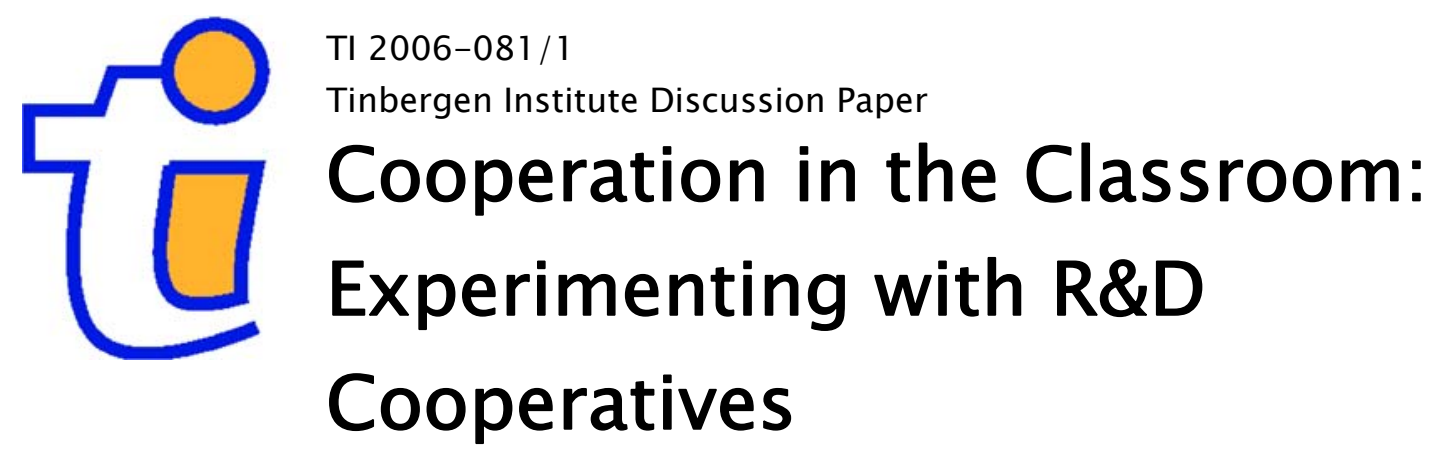

Michelle Sovinsky Goeree'
Jeroen Hinloopen

${ }^{1}$ Claremont McKenna College,

2 Universiteit van Amsterdam, Tinbergen Institute, and Kath. Universiteit Leuven. 


\section{Tinbergen Institute}

The Tinbergen Institute is the institute for economic research of the Erasmus Universiteit Rotterdam, Universiteit van Amsterdam, and Vrije Universiteit Amsterdam.

Tinbergen Institute Amsterdam

Roetersstraat 31

1018 WB Amsterdam

The Netherlands

Tel.: $\quad+31(0) 205513500$

Fax: $\quad+31(0) 205513555$

Tinbergen Institute Rotterdam

Burg. Oudlaan 50

3062 PA Rotterdam

The Netherlands

Tel.: $\quad+31(0) 104088900$

Fax: $\quad+31(0) 104089031$

Most TI discussion papers can be downloaded at http:/ /www.tinbergen.nl. 


\title{
Cooperation in the Classroom: Experimenting with R\&D Cooperatives
}

\author{
Michelle S. Goeree and Jeroen Hinloopen ${ }^{1}$
}

August 2005, revised September 2006

\begin{abstract}
$\underline{\text { Abstract }}$
This paper describes a classroom experiment that illustrates the research and development investment incentives facing firms when technological spillovers are present. The game involves two stages in which student sellers first make investment decisions then production decisions. The classroom game can be used to motivate discussions of research joint ventures, the free-rider problem, collusion, and antitrust policy regarding research and development.
\end{abstract}

Keywords: classroom games, research and development, research joint ventures, technological spillovers.

JEL codes: C91, L13, L41.

\footnotetext{
${ }^{1}$ Goeree is at Claremont McKenna College; Hinloopen is at the University of Amsterdam, Tinbergen Institute, and Katholieke Universiteit Leuven. The corresponding author is Goeree: Claremont McKenna College, 500 E. Ninth Street, Claremont, CA 91711 USA. We would like to thank Jacob Goeree and three anonymous referees for constructive comments. All remaining errors are ours.
} 


\section{Introduction}

In 2004, firms in the U.S. spent over $\$ 312$ billion on research and development (R\&D) - nearly 3\% of GDP. The U.S. is far from unique in this dimension; in fact, firms in many countries spend substantial amounts on R\&D each year. Indeed, according to the Organization for Economic Co-operation and Development (OECD), Israel spent 4.9\% of GDP on R\&D in 2000-2003. Within the European Union (EU), the share of GDP spent on R\&D in 2000-2003 varied greatly across countries with the largest fraction spent in Sweden and Finland, at $4.2 \%$ and $3.5 \%$ respectively. ${ }^{2}$ Understanding firms' incentives to invest and the role for governmental policy is an important part of any course in Industrial Organization and is relevant to many applied courses including Game Theory, Economics of Innovation, Law and Economics, Economics of Regulation, and Antitrust Policy.

Investment in $R \& D$ is distinct from capital investments along two dimensions. First, there is a public good aspect associated with $R \& D$. That is, the use of an innovation does not diminish its availability to other firms. ${ }^{3}$ This suggests it may be welfare improving to make the innovation available to other firms. In addition, the understanding obtained from investment spills over freely to others. These technological spillovers reduce firms' incentives to invest since rivals may benefit from their costly innovation. ${ }^{4}$ While the magnitude varies across industries and countries, empirical studies indicate R\&D spillovers are significant in many markets. ${ }^{5}$ As noted by Griliches (1992), in many industries "R\&D spillovers are present, their magnitude may be quite large, and social rates of return remain significantly above private rates."

The literature has proposed several solutions to the public good and externality problems associated with R\&D. One solution is to allow cooperation in investment decisions. The coordination of R\&D improves investment incentives when spillovers exist, especially when they are high. In the 1980's U.S. authorities responded to the theoretical findings by passing the National Cooperation Research Act (NCRA), which permits firms to cooperate in R\&D. ${ }^{6}$ The NCRA was amended in 1993 to include production joint ventures.

\footnotetext{
${ }^{2}$ Source: www.nsf.gov/statistics/infbrief/nsf06306

${ }^{3}$ See Arrow (1962) for an early analysis of this aspect of R\&D in relation to market structure.

${ }^{4}$ One way to diminish this leakage of information is to apply for a patent. Patents, however, do not optimally protect innovations (Mansfield, 1985). Moreover, from a welfare point of view, patents carry a fundamental cost; the marginal cost of information sharing is often close to zero whereas a patent allows the innovator to charge the monopoly price. For more on this topic see Spence (1984), d'Aspremont and Jacquemin (1988), Kamien et al. (1992), and Amir (2000). ${ }^{5}$ See Griliches (1992) and Nadiri (1993) for surveys of the literature on estimation of spillovers.

${ }^{6}$ According to the NCRA, a research joint venture is 'any group of activities, including attempting to make, making or performing a contract, by two or more persons for the purposes of - (a) theoretical analysis, experimentation, or systematic study of phenomena or observable facts, (b) the development or testing of basic engineering techniques, (c) the extension of investigative finding or theory of a scientific or technical nature into practical application for experimental and demonstration purposes..., (d) the collection, exchange, and analysis of research information, or (e)
} 
Shortly after the passage of the NCRA, 14 leading semiconductor firms formed the consortium for Semiconductor Manufacturing Technology (Sematech). Sematech was formed to increase the return to R\&D by increasing the extent to which new knowledge could be internalized. In general, due to the steep learning curves in production of memory chips and microprocessors, firms in the semiconductor industry can realize large efficiency gains from joint ventures (Irwin and Klenow, 1996). More recently in the semiconductor industry, Advanced Micro Devices and Fujitsu entered into a joint venture (Spansion) to research flash memory. In short, there have been numerous $R \& D$ cooperatives in many industries since the NCRA was enacted. For example, Xerox and DuPont formed a joint venture to develop copying equipment; IBM and Sears to provide electronic information services; General Motors and Toyota to produce a new type of car; GE and Ford to develop lighting systems; Merck and Johnson \& Johnson to develop new over the counter medicines; and $\mathrm{ABC}, \mathrm{NBC}, \mathrm{CBS}$ and Cable News Network to conduct exit polls and pool information during national elections. Currently, $R \& D$ cooperatives are permitted in many jurisdictions, including the EU, the US, and Japan.

A potential drawback of allowing R\&D cooperatives is that they may increase the likelihood of coordination in the final goods market by member firms. That is, the joint R\&D venture can act as a forum to discuss product market prices (Martin, 1995 and Lambertini, et. al., 2002). Indeed, according to Scherer (1980), the "most egregious price fixing schemes in American history" were brought about by research cooperatives. While R\&D cooperatives are legal in many countries all legal systems make a distinction between joint $\mathrm{R} \& \mathrm{D}$ decisions and joint production decisions, where the latter is illegal (Jorde and Teece, 1990).

In summary, discussions about R\&D investments include many issues that students typically find difficult to grasp: positive externalities, free-rider behaviour, tacit collusion, and private and social benefits to R\&D. We present a classroom game that illustrates the $R \& D$ investment incentives facing firms, particularly in markets where technological spillovers are high, as an aid for teaching these issues. It involves a two-stage game in which student "sellers" make investment decisions in the first stage and production decisions in the second stage. R\&D investments reduce the seller's second stage costs of production but may also reduce rivals' cost of production. We present many treatments, which can be implemented individually or together, depending upon classroom time constraints. The treatments demonstrate the free-rider problem in investment decisions when technological spillovers are present, how $R \& D$ cooperatives can be used to alleviate incentive problems, and the temptation to coordinate on final good production when coordination of $R \& D$ investments is permitted. The observed decisions in this experiment can be used to stimulate

any combination of the.' Unfortunately, the academic literature is not consistent regarding classification of the different forms of R\&D cooperatives. Throughout this paper, we follow the definitions of Kamien, e.t al., (1992) (see Section 2). 
discussions of spillovers, several types of R\&D cooperatives, tacit (or explicit) collusion, and antitrust and competition policy regarding investment in innovations. The game is intended for students in second to fourth year economics courses. To aid classroom discussion of experimental results, we summarize results from experiments conducted in Industrial Organization classes at the University of Amsterdam.

\section{Overview}

The experimental set-up is based on the seminal model of Kamien, et. al., (1992), hereafter KMZ. ${ }^{7}$ The experiment consists of many independent markets in which the same good is exchanged. Each student is one of two sellers in one of the markets. Every seller has ten widgets to sell per period. Each trading period is a two-stage game in which sellers choose how much to invest in R\&D in the first stage. R\&D investment reduces production costs in the second stage in which sellers are Cournot competitors in the final goods market. This two-stage game is played for a number of periods and the cost reduction due to investment in $R \& D$ is valid only for the period in which the investment is made. In particular, every unit investment results in a cost reduction of the square root of the number of units invested. After all sellers have made their investment decisions, the decisions are displayed on the blackboard. Sellers then determine the number of widgets they wish to sell. The price earned for each widget sold is 40 minus the total number of widgets sold by both sellers in the market. When all sellers have made their quantity decisions, the trading period ends.

There are three variations of the classroom experiment and the decision sheets for each treatment are provided in Appendix B. Each of the four treatments can be conducted alone or in combination with any other treatment depending upon classroom time constraints and the economic concepts you wish to emphasize. In the baseline treatment cooperation among sellers in R\&D investments is not permitted and a seller's own investment decision determines her costs of production (i.e. there are no investment spillovers). Treatments 2 through 4 are best used in combination with the baseline treatment and can be divided into two groups: those that permit coordination in $\mathrm{R} \& \mathrm{D}$ decisions and those that do not. For a summary, see Table 1.

Table 1 Treatment Summary

\begin{tabular}{llll}
\hline & \multicolumn{2}{c}{ Cooperation in R\&D } \\
\cline { 3 - 4 } & & Not permitted & Permitted \\
\hline \multirow{2}{*}{$\begin{array}{l}\text { Technological } \\
\text { Spillover }\end{array}$} & Not present & Treatment 1 (Baseline) & Treatment 2 (R\&D - cartel) \\
\cline { 2 - 4 } & Present & Treatment 3 (RJV-competition) & Treatment 4 (RJV-cartel) \\
\hline
\end{tabular}

\footnotetext{
${ }^{7}$ While there are other models of innovation, KMZ allows for a simple presentation of the role of spillovers, of the effects of R\&D cooperation, and of the potential for product market collusion, which makes it ideal for our purposes.
} 
In treatment 2, sellers are permitted to coordinate their investment decisions (but not final goods production). The experiment is designed such that coordinated $\mathrm{R} \& \mathrm{D}$ decisions are binding, i.e. in the experiment sellers cannot deviate from the cooperative R\&D levels chosen in their agreement (see section 3 for procedural details). As in the baseline treatment, the seller's own investment determines her costs. KMZ label this scenario 'R\&D-cartel'. The second treatment illustrates the effects of $R \& D$ cooperation when investment spillovers are not present. Theory predicts R\&D investments will decline under this treatment because coordination reduces investments to the joint monopoly level while there are no positive externalities to internalize (d'Aspremont and Jacquemin, 1988).

In the third treatment a seller's cost is reduced by the total amount of investment undergone by both sellers (i.e. there are full investment spillovers), but sellers are not permitted to cooperate in R\&D decisions. This scenario is labelled 'Research Joint Venture Competition' (RJV-Competition) by KMZ. Treatment 3 illustrates the free-rider problem arising from full investment spillovers. ${ }^{8}$ Theory predicts RJV-Competition yields the lowest levels of R\&D investments of all treatments considered.

The final treatment allows for cooperation in R\&D investments under full spillovers (RJV-Cartel). ${ }^{9}$ Treatment 4 illustrates the benefits and drawbacks of $R \& D$ cooperation. R\&D cooperation is beneficial in that it alleviates the free-rider problem in R\&D investments (present in treatment 3). However, while in the research lab firms may discuss non-R\&D related market strategies with rivals facilitating illegal collusion in the product market. An interesting feature of treatment 4 (and 2) is that you may observe (illegal) collusion in quantity decisions arising from the contact sellers make during $R \& D$ decisions. This provides an opportunity to discuss antitrust policy with regard to collusion and R\&D cooperatives (Martin, 1995).

While each of the treatments can be conducted individually, it is most informative to discuss results relative to the baseline case (treatment 1). Since the time necessary to perform all treatments exceeds a typical

\footnotetext{
${ }^{8} \mathrm{We}$ focus on minimal and maximal spillovers to highlight the typical aspects of R\&D investments. It is straightforward to modify the experiment to include any intermediate value of spillovers. In particular, rather than stating that production costs are reduced by the square root of total R\&D investments (i.e. the case of full spillovers), you can indicate that the cost reduction equals the square root of anyone's own R\&D investment plus, say, half of what one's rival invests (i.e. spillovers are 50\%).

${ }^{9}$ We assume spillovers are exogenous. Formation of an R\&D cooperative does not influence the rate of technological spillover. See KMZ and Amir, Evstigneev, and Wooders (2003) for models with endogenous spillovers. In addition, we assume firms are able to realize the exogenous spillovers. The instructor may wish to note that in practice firms may have to invest in "absorptive capacity" in order to realize R\&D spillovers. For more on this topic see Cohen and Levinthal (1989) and Kamien and Zang (2000).
} 
classroom allotment, Table 2 provides a summary of some of the possible treatment combinations, related economic concepts, and time allocation recommendations (including time for discussion).

Table 2 Time Allocation Recommendations

\begin{tabular}{lll}
\hline Treatment(s) & Economic Concepts & Time \\
\hline 1 & two-stage game & 30 minutes \\
& & \\
1 and 2 & inefficiency of R\&D-cartels & treatment $1-20$ minutes \\
& collusion & treatment $2-30$ minutes \\
& & \\
1 and 3 & technological spillovers & treatment $1-20$ minutes \\
& free-rider problem & treatment $3-30$ minutes \\
& & \\
1 and 4 & technological spillovers & treatment $1-20$ minutes \\
& efficiency of RJV-cartels & treatment $4-40$ minutes \\
& collusion & \\
\hline
\end{tabular}

\section{Procedures}

In preparation for the experiment you will need to make copies of the instructions and the decision sheets in the appendices, and set up a record table on an overhead transparency or on a blackboard. Per market (i.e. per pair of students) the record table should contain one column for the investment decision and one for the quantity decision with enough rows for about five periods. In each cell you will record the decision made by each seller in each period. You will need two assistants, one to help gather decision sheets and one to help record results. If you plan to conduct treatments 3 or 4, you should make copies of Table C1 in Appendix C, which gives cost reductions for large total R\&D investments.

Before starting the experiment, select two student assistants. Ask the assistants to distribute the instructions, and, while they are doing so, count the students and determine how many markets and sellers you wish to have. In general, five markets with two sellers in each works well (resulting in ten sellers). Rather than increasing the number of sellers for larger classes, we have found that allowing students to work in pairs, 
where two (or three) students represent one seller decreases the amount of time necessary to conduct the experiment and enhances understanding. ${ }^{10}$

Number the decision sheets accordingly with a different number for each seller. To prevent sellers in the same market from interacting, the groups of sellers should be seated in separate areas of the room. For example, for an experiment with six sellers arrange three on one side of the room (say sellers numbers 1-3) and the remaining (numbers 4-6) on the other. Once the sellers are seated, distribute the decision sheets and read the instructions aloud. The students may have questions at this point but try to keep discussion to a minimum.

After the first round of investment decisions, ask an assistant to collect the decision sheets. At this time the sellers in each group are randomly assigned to a market. For example, to assign sellers randomly to a market for an experiment involving 3 markets with 2 sellers each, shuffle the decision sheets for the first three sellers then randomly choose one of the sheets - the chosen seller is assigned to the first market, the second seller drawn is assigned to the second market, etc. Shuffle the decision sheets for the other three sellers (numbers 4-6) and assign markets analogously. This random assignment of sellers over markets can be done in each period or only initially. ${ }^{11}$ As we discussed in section 2, one interesting feature of this experiment is that (tacit) collusion in the product market may occur in treatments 2 and 4 . If you plan to discuss the potential for collusive behaviour, we recommend assigning sellers to each market once at the beginning of the experiment as collusion is easier to sustain when the same sellers compete with each other for several periods (see, e.g. Ellison, 1994).

Record on the blackboard the amount each seller has invested in each market. Return the decision sheets and ask sellers to calculate their costs. Table C1 (in Appendix C) contains cost calculations for R\&D investments between 1 and 50 units. Although the calculations are straightforward, we have found distributing Table $\mathrm{C} 1$ to the students (or projecting it on an overhead projector) speeds the process when conducting treatments 3 and 4 .

After the sellers have calculated their costs, ask them to make their production decision. Collect the decision sheets, record the production decisions on the blackboard, and redistribute the decision sheets so sellers can

\footnotetext{
${ }^{10}$ For more on group versus individual decision making see Bornstein and Yaniv (1998) and Blinder and Morgan (2000).

${ }^{11}$ The Instructions provided in Appendix A are written for initial random assignment but can be modified to allow for random assignment every period.
} 
determine the price in their market. ${ }^{12}$ Ask sellers to determine their profits (and cumulative profits) by filling out the rest of their decision sheet for this period. After sellers have calculated their profits, begin the next period by asking every seller to make a new investment decision.

In treatments 2 and 4 coordinated investments are permitted. At the beginning of each period in treatments 2 and 4, sellers in each market must sit together so they can discuss their investment decisions. To start the period ask one seller from each market to move (temporarily) to the other side of the room to be seated next to his rival. Ask sellers to begin the experiment by talking with their rival and jointly determining investment decisions. Once they have reached a mutually agreeable decision sellers should record their own investments, the total market investment, and the resulting cost on their respective decision sheets. For the experiment to reflect economic theory, the $R \& D$ cooperation stage must be binding. That is, the coordinated-upon investment level must be the actual amount invested. To guarantee a binding decision the assistant should collect the decision sheets while rival sellers are seated together and should verify (with both sellers) that the recorded investment levels are correct. Following verification, the assistant records the investment on the blackboard while sellers return to their original seats.

After the sellers have returned to their seats, redistribute the decision sheets and ask the sellers to make their production decision. Collect the decision sheets, record the production decisions on the blackboard, and redistribute the decision sheets so sellers can determine the price in their market and their profits. After sellers have calculated their profits, begin the next period by asking sellers to be seated next to their rival and to determine their new investment decisions.

If you wish to discuss the potential for product market collusion, we recommend repeating treatment 2 or 4 for a few periods until you observe choices consistent with collusion (decreased output). Tacit collusion in finite supergames typically breaks down several periods before the last period (Selten and Stoecker, 1986). This suggests that an alternative way to detect collusive behaviour is to mention at the start of the final round that it is the last round. As we discuss in section 4, in markets with tacitly colluding sellers, announcing the final round hindered coordination and typically yielded (much) larger production levels in the classroom experiments we conducted.

Table 3 summarizes equilibrium investments and production levels for all treatments for the demand and cost specifications mentioned earlier including the equilibrium levels arising from collusion in the product

\footnotetext{
${ }^{12}$ Alternatively, after writing the production levels on the blackboard, you can record the resulting market price. If you intend to do this reserve enough space to include the market price on the record table.
} 
market. ${ }^{13}$ As the table indicates, for the parameter values chosen in this experiment $R \& D$ investments are lowest in treatment 3 (due to free-riding) and they increase when R\&D cooperatives are permitted in treatment 4. Not surprisingly, product market collusion results in lower production levels, increased profits at the expense of consumers, and an overall increase in deadweight loss, relative to treatments without product market collusion. An obvious parallel between both stages of the production chain exists in that coordination of R\&D decisions and coordination of production decisions always (weakly) increases firm profits. Indeed, the agreed-upon investment and production levels can always coincide with the noncooperative Nash outcomes.

Table 3 Nash equilibrium values; $a=40, c=25$ (see Appendix D).

\begin{tabular}{lrrrrr}
\hline Treatment & R\&D & Production & Consumer surplus & Per-firm profits & Total surplus \\
\hline 1 & 18.4 & 6.4 & 82.7 & 23.0 & 128.6 \\
2 & 3.5 & 5.6 & 63.3 & 28.1 & 119.5 \\
2 + product market collusion & 4.6 & 4.3 & 36.7 & 32.1 & 101.0 \\
3 & 1.8 & 5.6 & 63.3 & 29.9 & 123.1 \\
4 & 9.2 & 6.4 & 82.7 & 32.1 & 146.9 \\
$4+$ product market collusion & 12.5 & 5.0 & 50.0 & 37.5 & 125.0 \\
\hline
\end{tabular}

Coordination of R\&D investments may lead to increased consumer surplus if coordination results in larger investments. Whether increased investments are a result of $R \& D$ cooperation depends upon the extent of technological spillover in the market (d'Aspremont and Jacquemin, 1988). On the other hand, profitable coordination of production always leads to a reduction in total output, and hence to a reduction of consumer surplus. A "social dilemma" arises regarding the production decision: if firms are able to coordinate, they restrict production to increase profits while reducing consumer surplus. More interestingly, a social dilemma can arise when firms cooperate in $R \& D$ : coordination of $R \& D$ investments enhances profits while it reduces consumer surplus if coordination implies a reduction in R\&D efforts. Indeed, Katz (1986) and Leahy and Neary (1997) find that R\&D cooperatives may negatively affect welfare when R\&D spillovers are low. The rationale is that $\mathrm{R} \& \mathrm{D}$ cooperation acts as a surrogate for product market collusion, resulting in decreased production and R\&D investment. However, in practice, evidence indicates that spillovers are high

\footnotetext{
${ }^{13}$ The equilibrium values correspond to a stylized version of KMZ presented in Appendix D. We chose parameter values such that the Nash equilibrium quantities do not change significantly across treatments, while there is substantial variance in equilibrium R\&D investment levels across treatments. This specification was used both to ease discussion and to help students focus foremost on the R\&D investment decision. We provide an excel sheet (posted on the journal's website) that can be used to generate the equilibria for any parameterization of demand, cost, and spillovers for all treatments including product market collusion.
} 
and R\&D cooperatives leads to improved welfare, especially when cooperatives facilitate information sharing among consortium members.

\section{Discussion of results}

Students will be eager to discuss profits. Begin by asking who earned the highest cumulative profit and which treatments were more profitable. Lead the students to the understanding that profits are directly related to investment decisions. For instance, you can ask students if they choose different investment levels in the different treatments and why. For treatments involving spillovers, students may not immediately realize that spillovers in investments result in a free-rider problem, but a way to reach this understanding is to ask some leading questions. You may want to ask those students who invested less in the final periods why they reduced their investment levels. Typically the students were either responding to low investment levels of their rival (due to the rival free-riding) or trying to free-ride off the rival's investments. The students should reach this understanding quite naturally and, if they have had some game theory courses, may relate the situation to that of the prisoners in the prisoner's dilemma game.

Students may be interested if there are spillovers and how they arise. This type of discussion leads naturally into a lecture on R\&D incentives. You can ask students for suggestions of ways to alleviate this problem. Is there a role for the government? Should collusion in R\&D be legal under certain circumstances? The classroom discussion can then progress to the benefits of R\&D cooperatives and the prevalence of them in various industries such as the semiconductor industry and the mining and manufacturing industry. ${ }^{14}$

In treatment 4 sellers may form RJV-cartels and, as Table 3 illustrates, R\&D investments increase relative to treatment 3 . This is because the free-rider problem accompanying technological spillovers is overcome by coordination of R\&D investments. You can begin the discussion by asking sellers if they choose different investment levels in treatment 4 and why. If you had the time to conduct treatment 3 prior to 4 , then the benefits of RJV-cartels will be evident. For instance, you could highlight the trend in investment levels from your experiment. This is illustrated in Figure 1 where the average per-period R\&D investment levels are shown for treatments 1, 3 and 4 as they emerged in experiments conducted during a summer school of the Economics Network for COmpetition and REgulation (ENCORE). ${ }^{15} \mathrm{We}$ found, on average, a highly significant increase in $R \& D$ investments $(t=5.9)$. Alternatively you could focus on a seller who invested less than in the baseline treatment and ask why they choose to do so. Here there are two forces at work. On

\footnotetext{
${ }^{14}$ See Link (1996) for an overview of research joint venture filings and the Introduction for some specific examples.

15 Participants in the ENCORE summer school were mostly government officials of the Dutch antitrust authority (NMa), the Dutch telecom regulator (OPTA) and the Dutch Ministry of Economic Affairs.
} 
the one hand technological spillovers reduce $R \& D$ investment incentives as they reduce rivals' production cost. On the other hand both sellers benefit from rivals' $R \& D$ investments. The predicted drop in $R \& D$ investment due to the technological spillover can thus be reduced due to coordination of the $R \& D$ investment decision.

Figure 1 Average investment decisions during an ENCORE summer school

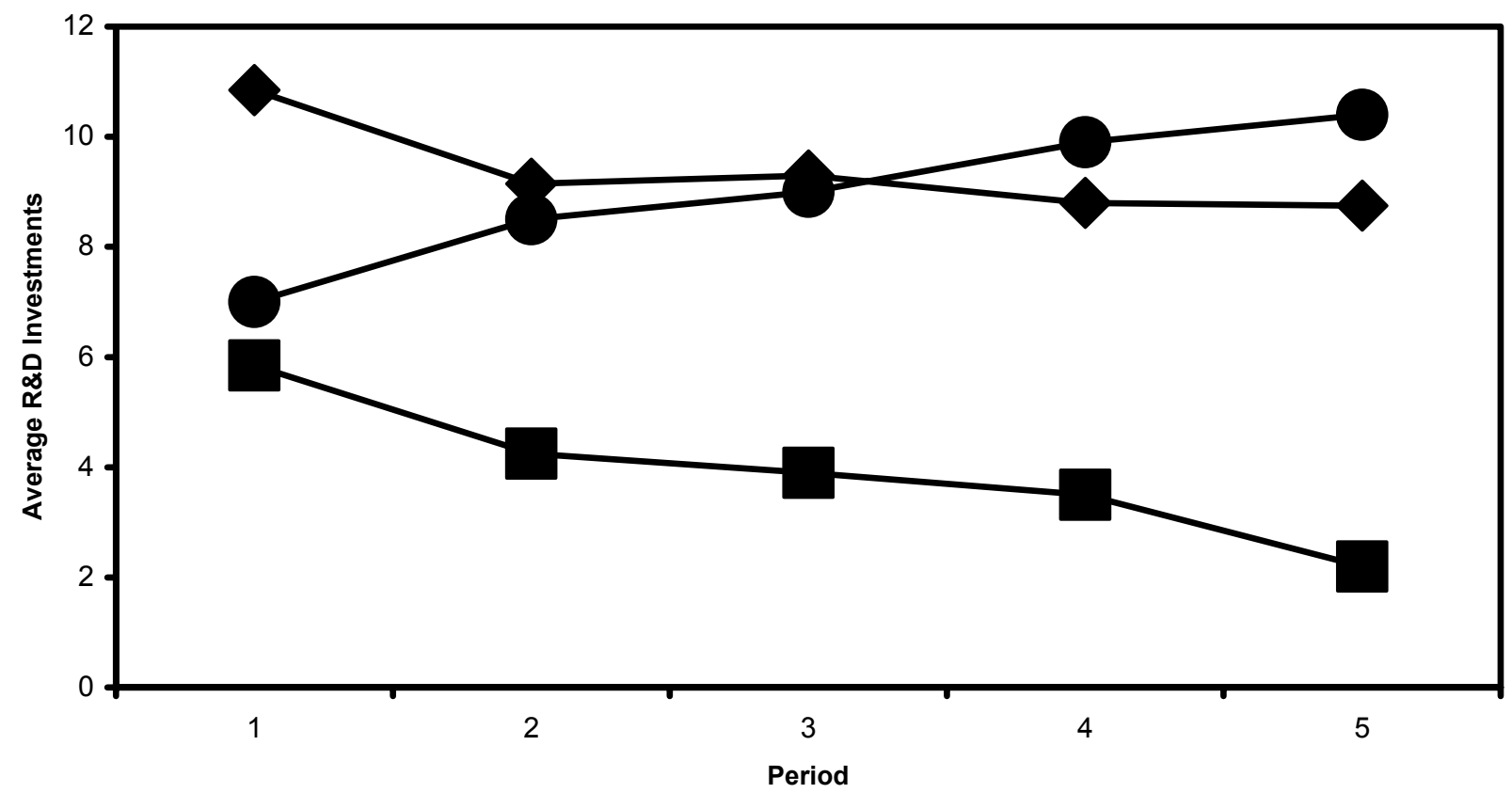

Non-cooperative R\&D, no spillovers $\rightarrow$ Non-cooperative R\&D, full spillovers

Cooperative R\&D, full spillovers

If you did not conduct treatment 3, you can ask students if they would have invested the same amount if they were not making the decision jointly. If the free-rider problem isn't evident, you could single out a student and ask her what she would do if her rival invested 25 and why. Regardless of her answer, you can ask the class if anyone would have made a different decision.

Once you have finished discussion surrounding the benefits of RJV-cartels, you can discuss potential drawbacks. You may have observed (illegal) cooperation in production levels. Students will typically respond honestly to the question, "were any of you deciding jointly how much to produce?" If output is set jointly then some students may defect by increasing their final round output level. We observed final round defection in the form of increased outputs in the majority of the experiments we conducted. Figure 2 contains the average per-period output decisions corresponding to the results in Figure 1. It suggests indeed that in treatment 4 , in some markets, production levels were jointly set (although the average production in 
the second-to-last period, 5.0, does not differ in a statistical sense from the average production of 5.6 in the last period; $t=1.3$ ).

Figure 2 Output results during an ENCORE summer school

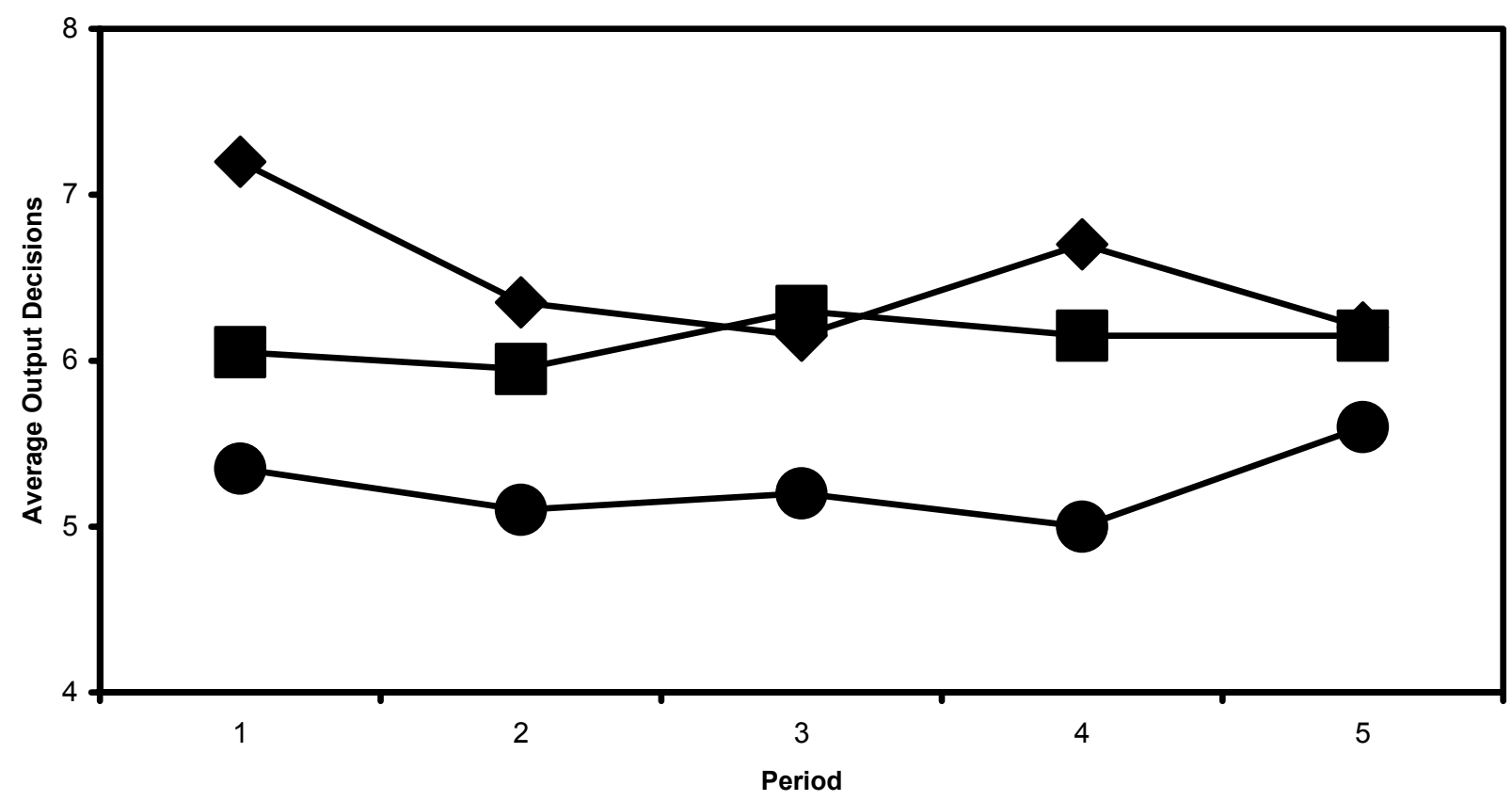

$\longrightarrow$ Non-cooperative R\&D, no spillovers $\rightarrow$ Non-cooperative R\&D, full spillovers $\longrightarrow$ Cooperative R\&D, full spillovers

These results can motivate discussion of antitrust policy and the fine line between encouraging investment while prohibiting collusion on output. To illustrate this trade-off you can discuss total welfare results under different treatments, as in Table 3.

Finally, it is worthwhile to highlight the two-stage nature of the game. To do so, you could ask students if they considered their quantity choices when making their investment decisions. Further discussion of the form "so you thought about your last decision before making your first decision?" leads into an explanation of how to find an equilibrium in a multi-stage game (by starting at the last stage).

Table 4 presents results from a number of classroom experiments conducted in Industrial Organization courses at the University of Amsterdam. Note that our experimental outcomes were not always consistent with the levels predicted by theory (see Table 3). Therefore, it is possible that the outcome from your experiment will involve different levels than predicted by theory. The results suggest that questions of the form: "Did you invest more or less (relative to other treatments)?" rather than, "How much did you invest?" 
will be more successful in getting across the economic concepts that the experiment is intended to emphasize.

Table 4 Average results from classroom experiments conducted at the University of Amsterdam

\begin{tabular}{lllll}
\hline Treatment & \multicolumn{2}{l}{ R\&D investments } & Production & \\
\hline & Outcome & $\begin{array}{l}\text { Statistically different from } \\
\text { theoretical prediction? }\end{array}$ & Outcome & $\begin{array}{l}\text { Statistically different from } \\
\text { theoretical prediction? }\end{array}$ \\
\hline 1 (baseline) & 13.3 & Yes & 6.3 & no \\
\cline { 2 - 6 } 2 (R\&D cartel) & 11.6 & Yes & 5.8 & no \\
3 (RJV-competition) & 6.9 & Yes & 5.8 & no \\
nyyyyy (RJV-cartel) & 18.4 & Yes & 5.6 & yes \\
\hline
\end{tabular}

It is worth noting that the average production values compare well the theoretical predictions. We conjecture that this is in part due to our parameter choices that make the equilibrium production levels of all four treatments almost identical. Further, comparing treatment 3 to treatment 1, we see that when spillovers are present but sellers are not permitted to cooperate in $R \& D$ decisions, $R \& D$ investment levels fall relative to the benchmark treatment (this drop is significant in a statistical sense according to a standard t-test: $t=3.2$ ).

\section{Further Reading}

This paper describes an experimental game designed for use in undergraduate classrooms. The experiment can be used to teach concepts related to R\&D cooperatives, spillovers, collusion, and government antitrust policy regarding investment in innovation. Our classroom paper is in the spirit of many others used as an aid in teaching topics common to Industrial Organization such as predatory pricing behaviour, asymmetric information, rent seeking behaviour, and auctions. ${ }^{16}$ Wells (1991) and Williams and Walker (1993) provide surveys of the classroom experimental literature.

In addition to classroom experiments, numerous laboratory experiments explore issues related to Industrial Organization. Suetens (2005) investigates whether R\&D cooperation leads to product market collusion for different levels of spillovers. She finds that the degree of price collusion in the final goods market is higher when RJV-cartels are permitted. Finally, Holt (1995) and Chapter 7 of Davis and Holt (1993) provide an extensive survey of the experimental Industrial Organization literature.

\footnotetext{
${ }^{16}$ See, for instance, Bergstrom and Miller (1997), Goeree and Holt (1999), Holt and Sherman (1999), and Capra, et. al., (2000) as well as the ongoing Classroom Games column in the Journal of Economic Perspectives edited by Holt.
} 


\section{References}

Amir, R (2000), "Modelling Imperfectly Appropriable R\&D via Spillovers," International Journal of Industrial Economics, 18(7): 1013-1032.

Amir, R, Evstigneev I., and J. Wooders (2003), "Noncooperative versus Cooperative R\&D with Endogenous Spillover Rates,” Games and Economic Behavior 42: 183-207.

Arrow, K. J., 1962, "Economic welfare and the allocation of resources for invention", in Nelson, R. R. (ed.), The rate and direction of innovative activity: economic and social factors, Princeton: Princeton University Press, $606-626$.

d'Aspremont, C. and A. Jacquemin (1988), “Cooperative and noncooperative R\&D in duopoly with spillovers", American Economic Review, 78(5): 1133 - 1137.

Bergstrom, T. and J. Miller (1997), Experiments with Economic Principles, New York: McGraw Hill.

Blinder, A.S. and Morgan, J. (2000), “Are two heads better than one? An Experimental Analysis of Group vs. Individual Decision Making,” NBER Working Paper 7909.

Bornstein, G. and Yaniv, I. (1998), "Individual and Group Behavior in the Ultimatum Game: Are Groups More 'rational' players?” Experimental Economics, 1: 101-108.

Capra, M. C., Goeree, J. K., Gomez, R. and C. Holt (2002), "Predation, asymmetric information, and strategic behaviour in the classroom: an experimental approach to the teaching of Industrial Organization," International Journal of Industrial Organization, 18(1): 205 - 225.

Cohen, W.M. and D.A. Levinthal (1989), "Innovation and Learning: the two faces of R\&D," Economic Journal, (94): 569-596.

Davis, D. and C. Holt (1993), Experimental Economics, Princeton: Princeton University Press.

Ellison, G. (1994), “Cooperation in the prisoner's dilemma with anonymous random matching”, Review of Economic Studies, 61: 567 - 588.

Goeree, J. and C. Holt (1999), "Rent seeking and the inefficiency of non-market allocations", Journal of Economic Perspectives, 13(3): 217 - 226.

Griliches, Z. (1992) “The Search for R\&D Spillovers," Scandinavian Journal of Economics, (94): $29-47$.

Holt, C (1995), "Industrial Organization: a survey of laboratory research", in Kagel, J. and A. Roth, eds., Handbook of Experimental Economics, Princeton: Princeton University Press, 349 - 443.

Holt, C. and R. Sherman (1999), "Classroom games: a market for lemmons", Journal of Economic Perspectives, 13(1): $205-214$.

Irwin, D. and P. Klenow (1996), "Sematch: Purpose and Performance," Proceedings of the National Academy of Sciences, 93: 12739-12742. 
Jorde, M. and D. Teece (1990), "Innovation and cooperation: implications for competition and antitrust", Journal of Economic Perspectives, 4(3): 75 - 96.

Kamien, M. I., Muller, E. and I. Zang (1992), "Research joint ventures and R\&D cartels", American Economic Review, 82(5): 1293 - 1306.

Kamien, M.I, and I. Zang (2000), "Meet me halfway: Research Joint Ventures and Absorptive Capacity,” International Journal of Industrial Organization (18): 995-1012.

Katz, M. (1986), “An analysis of cooperative research and development," Rand Journal of Economics, 17:527-543.

Lambertini, L., S. Podder, and D. Sasaki (2002), "Research Joint Ventures, product differentiation, and price collusion," International Journal of Industrial Organization 20: 829-854.

Leahy, D. and J.P. Neary (1997), "Public Policy towards R\&D in Oligopolistic Industries," American Economic Review, 87:642-662.

Link, A. (1996), "Research Joint Ventures: Patterns from Federal Register Filings", Review of Industrial Organization, 11(5): 617 - 628.

Mansfield, E., 1985, “How rapidly does new industrial technology leak out?” Journal of Industrial Economics, XXXIV(2): $217-223$.

Martin, S (1995), "R\&D joint ventures and tacit product market collusion", European Journal of Political Economy, 11(4): 733 - 741.

Martin, S. (1997), "Public policies towards cooperation in Research and Development: the European Union, Japan, the United States", in Comanor, W, Goto A. and L. Waverman, eds., Competition in a global economy, London: Routledge.

Nadiri, M. (1993), "Innovations and Technological Spillovers,” NBER Working Paper 4423.

Scherer, F.M. (1980), Industrial Market Structure and Economic Performance. Chicago; Rand McNally College Publishing Co., pp. 430-431.

Selten, R. and R. Stoecker (1986), "End behaviour in sequences of finite prisoner's dilemma supergames; a learning theory approach”, Journal of Economic Behaviour and Organization, 7: 47 - 70.

Spence, M. (1984), “Cost reduction, competition, and industry performance”, Econometrica, 52(1): $101-121$.

Suetens, S. (2005), "Cooperative and noncooperative R\&D in experimental duopoly markets", International Journal of Industrial Organization, 23 (1-2): 63 - 82.

Wells, D. (1991), "Laboratory experiments for undergraduate instruction in economics", Journal of Economic Education, 22(3): 293 - 300. 
Williams, A. and J. Walker (1993), “Computerized laboratory exercises for microeconomics education: three applications motivated by experimental economics", Journal of Economic Education, 24(4): $291-315$. 


\section{Appendix A Instructions}

In this experiment there are many independent markets in which the same good is exchanged. Each of you is a seller in one of the markets for a series of periods. At the beginning of the experiment you will be randomly paired with another seller, so in each market there will be two sellers. During the experiment you will stay in the same market. Each of you has 10 widgets to sell. For each widget that you sell you will incur a basic cost of 25 that can be reduced through an investment. That is, in each period, you can decide to make an investment which will lower your costs for that period. Every unit investment results in a cost reduction of the square root of the number of units invested. So if you decide to invest 4 units your production costs will be reduced by $\sqrt{4}=2$. Each unit you invest costs 1 . You can invest at most 25 units and your investment decision must be positive and an integer (i.e. you cannot invest half a unit). The costs you pay per widget sold are determined in the following manner:

$$
\operatorname{cost}=25-\text { cost reduction }=25-\sqrt{\text { units invested }}
$$

The following table illustrates the cost reduction and resulting cost incurred from producing one widget for each investment level.

\begin{tabular}{|l|r|r|l|r|r|l|r|r|}
\hline invested & reduction & \multicolumn{1}{l|}{ cost } & invested & reduction & \multicolumn{1}{l|}{ cost } & invested & reduction & \multicolumn{1}{l|}{ cost } \\
\hline 1 & 1.0 & 24.0 & 10 & 3.2 & 21.8 & 19 & 4.4 & 20.6 \\
2 & 1.4 & 23.6 & 11 & 3.3 & 21.7 & 20 & 4.5 & 20.5 \\
3 & 1.7 & 23.3 & 12 & 3.5 & 21.5 & 21 & 4.6 & 20.4 \\
4 & 2.0 & 23.0 & 13 & 3.6 & 21.4 & 22 & 4.7 & 20.3 \\
5 & 2.2 & 22.8 & 14 & 3.7 & 21.3 & 23 & 4.8 & 20.2 \\
6 & 2.4 & 22.6 & 15 & 3.9 & 21.1 & 24 & 4.9 & 20.1 \\
7 & 2.6 & 22.4 & 16 & 4.0 & 21.0 & 25 & 5.0 & 20.0 \\
8 & 2.8 & 22.2 & 17 & 4.1 & 20.9 & & & \\
9 & 3.0 & 22.0 & 18 & 4.2 & 20.8 & & & \\
\hline
\end{tabular}

Once you have made your investment decision, write the number of units you wish to invest on your decision sheet, in the appropriate column for the current period. After all sellers have made their investment decisions we will collect your decision sheets and write the investment decisions on the blackboard. 
When all of the decisions have been recorded on the blackboard we will return the decision sheets to you. You will then be asked to choose the number of widgets you wish to sell. All widgets that you sell will be sold at the same price. You can sell at most 10 widgets and the number of widgets offered must be positive and an integer. You must write the number of widgets you selected on your seller decision sheet, in the appropriate column for the current period. After all sellers have chosen the number of widgets to sell, the decision sheets will be collected and the quantity decisions will be written on the blackboard. When all of the production decisions have been recorded on the blackboard we will return the decision sheets to you. The price you earn for each widget sold is 40 minus the total number of widgets sold by all sellers in your market. So if you decide to sell 4 widgets and the other seller in your group decides to sell 3 widgets then the sales price is:

$$
\text { sales price }=40-4-3=33 .
$$

When all sellers have made their quantity decisions the trading period ends and you can calculate your earnings for the period. Your earnings are determined in the following manner:

$$
\text { earnings }=(\text { sales price } \times \text { quantity sold })-(\text { unit cost } \times \text { quantity sold })-\text { units invested }
$$

Any questions? We will begin by having each seller choose an investment level, which you should record on your decision sheet. 


\section{Appendix B Decision sheets}

Decision sheets for treatments without technological spillovers (1 and 2)

Seller number:

period $1 \quad \operatorname{period} 2 \operatorname{period} 3 \quad$ period $4 \quad \operatorname{period} 5$

1) number of units you invest (max 25)

2) cost reduction (from table)

3) cost per widget (from table)

\begin{tabular}{|l|l|l|l|l|} 
& & & & \\
\hline & & & & \\
\hline & & & & \\
\hline
\end{tabular}

The decision sheets will be collected, all investments will be written on the blackboard, and the decision sheets will be returned again

4) number of widgets you offer (max 10)

The decision sheets will be collected, all widget offers will be written on the blackboard, and the decision sheets will be returned again

5) total number of widgets offered in your market (see blackboard)

6) price $=40-$ line (5)

7) price $\times$ quantity $=$ line $(6) \times$ line $(4)$

8) production cost $\times$ your production $=$ line $(3) \times$ line $(4)$

9) profit $=$ line (7) - line (8) - line (1)

10) cumulative profit

\begin{tabular}{|l|l|l|l|l|} 
& & & & \\
\hline & & & & \\
\hline & & & & \\
\hline & & & & \\
\hline & & & & \\
\hline & & & & \\
\hline
\end{tabular}


Decision sheets for treatments with full technological spillovers (3 and 4)

Seller number:

\section{period $1 \quad$ period $2 \quad$ period $3 \quad$ period $4 \quad$ period 5}

1) number of units you invest ( $\max 25)$

2) total investment in your market

3) cost reduction (from table)

4) cost per widget (from table)

\begin{tabular}{|l|l|l|l|l|} 
& & & & \\
\hline & & & & \\
\hline & & & & \\
\hline & & & & \\
\hline
\end{tabular}

The decision sheets will be collected, all investments will be written on the blackboard, and the decision sheets will be returned again

5) number of widgets you offer (max 10)

The decision sheets will be collected, all widget offers will be written on the blackboard, and the decision sheets will be returned again

6) total number of widgets offered in your market (see blackboard)

7) price $=40-$ line (5)

8) price $\times$ quantity $=$ line $(6) \times$ line $(4)$

9) production cost $\times$ your production $=$ line $(3) \times$ line $(4)$

10) profit $=$ line $(7)-$ line $(8)-$ line (1)

11) cumulative profit

\begin{tabular}{|l|l|l|l|l|} 
& & & & \\
\hline & & & & \\
\hline & & & & \\
\hline & & & & \\
\hline & & & & \\
\hline & & & & \\
\hline
\end{tabular}




\section{Appendix C Table C1: Large R\&D investments}

\begin{tabular}{|c|c|c|c|c|c|}
\hline units invested & cost reduction & cost & units invested & cost reduction & cost \\
\hline 1 & 1.0 & 24.0 & 26 & 5.1 & 19.9 \\
\hline 2 & 1.4 & 23.6 & 27 & 5.2 & 19.8 \\
\hline 3 & 1.7 & 23.3 & 28 & 5.3 & 19.7 \\
\hline 4 & 2.0 & 23.0 & 29 & 5.4 & 19.6 \\
\hline 5 & 2.2 & 22.8 & 30 & 5.5 & 19.5 \\
\hline 6 & 2.4 & 22.6 & 31 & 5.6 & 19.4 \\
\hline 7 & 2.6 & 22.4 & 32 & 5.7 & 19.3 \\
\hline 8 & 2.8 & 22.2 & 33 & 5.7 & 19.3 \\
\hline 9 & 3.0 & 22.0 & 34 & 5.8 & 19.2 \\
\hline 10 & 3.2 & 21.8 & 35 & 5.9 & 19.1 \\
\hline 11 & 3.3 & 21.7 & 36 & 6.0 & 19.0 \\
\hline 12 & 3.5 & 21.5 & 37 & 6.1 & 18.9 \\
\hline 13 & 3.6 & 21.4 & 38 & 6.2 & 18.8 \\
\hline 14 & 3.7 & 21.3 & 39 & 6.2 & 18.8 \\
\hline 15 & 3.9 & 21.1 & 40 & 6.3 & 18.7 \\
\hline 16 & 4.0 & 21.0 & 41 & 6.4 & 18.6 \\
\hline 17 & 4.1 & 20.9 & 42 & 6.5 & 18.5 \\
\hline 18 & 4.2 & 20.8 & 43 & 6.6 & 18.4 \\
\hline 19 & 4.4 & 20.6 & 44 & 6.6 & 18.4 \\
\hline 20 & 4.5 & 20.5 & 45 & 6.7 & 18.3 \\
\hline 21 & 4.6 & 20.4 & 46 & 6.8 & 18.2 \\
\hline 22 & 4.7 & 20.3 & 47 & 6.9 & 18.1 \\
\hline 23 & 4.8 & 20.2 & 48 & 6.9 & 18.1 \\
\hline 24 & 4.9 & 20.1 & 49 & 7.0 & 18.0 \\
\hline 25 & 5.0 & 20.0 & 50 & 7.1 & 17.9 \\
\hline
\end{tabular}




\section{Appendix D Nash equilibria}

The model that we describe here is a special case of Kamien et al. (1992) in that the R\&D production function is made explicit and that only 2 rather than $n$ firms are considered. The spillover parameter $\beta$ is allowed to take on any value between 0 and 1 . For the treatments described in the text it is either 0 (treatments 1 and 2) or 1 (treatments 3 and 4). The equilibrium R\&D levels for these two special cases are also provided below.

\section{$\underline{\text { Set-up }}$}

Assume linear demand, $p=a-Q$, and constant marginal cost, c. Individual firm profits are: ${ }^{17}$

$$
\pi_{i}=(a-Q) q_{i}-\left(c-\sqrt{x_{i}+\beta x_{j}}\right) q_{i}-x_{i},
$$

$i, j=1,2, i \neq j$, where $Q=q_{1}+q_{2}$, is total production, where $x_{i}$ are $\mathrm{R} \& \mathrm{D}$ investments of firm $i$, and where $\beta \in[0,1]$ represents the technological spillover. Maximizing individual firm profits over quantities yields:

$$
q_{i}\left(x_{i}, x_{j}\right)=\frac{1}{3}\left[(a-c)+2 \sqrt{x_{i}+\beta x_{j}}-\sqrt{x_{j}+\beta x_{i}}\right] .
$$

Concomitant profits conditional on R\&D investments then equal $\pi_{i}=q_{i}\left(x_{i}, x_{j}\right)^{2} / 9-x_{i}$.

\section{Noncooperative R\&D}

Maximizing individual profits over individual R\&D investments yields as symmetric equilibrium:

$$
x_{i}^{N}=\frac{(a-c)^{2}(2-\beta)^{2}}{(7+\beta)^{2}(1+\beta)} .
$$

Noncooperative R\&D investments (treatment 1) are:

$$
\left.x_{i}^{N}\right|_{\beta=0}=\frac{4(a-c)^{2}}{9} \text {, }
$$

while individual R\&D investments in a RJV equal (treatment 3):

$$
\left.x_{i}^{N}\right|_{\beta=1}=\frac{(a-c)^{2}}{128} .
$$

Note that equilibrium investments determine the entire equilibrium of the game, including the values for consumer surplus and total surplus.

\section{Cooperative R\&D}

\footnotetext{
${ }^{17}$ For technical details of the model, see Kamien et al. (1992). The parameter values that we have chosen are such that in all treatments all necessary conditions are met for the resulting Nash equilibria to exist and to be unique.
} 
Maximizing joint industry profits over R\&D investments gives:

$$
x_{i}^{C}=\frac{(a-c)^{2}(1+\beta)}{(8-\beta)^{2}} .
$$

R\&D cartel investments are (treatment 2):

$$
\left.x_{i}^{C}\right|_{\beta=0}=\frac{(a-c)^{2}}{64}
$$

while individual investments within a RJV-cartel are given by (treatment 4):

$$
\left.x_{i}^{C}\right|_{\beta=1}=\frac{2(a-c)^{2}}{49} \text {. }
$$

